Open Access

\title{
Evolution of strategic interactions from the triple to quad helix innovation models for sustainable development in the era of globalization
}

\author{
Josphert Ngui Kimatu
}

Correspondence:

jkimatu@seku.ac.ke

Research Innovation and

Technology, Department of Biology,

South Eastern Kenya University, P.

O. Box 170-90200, Kitui, Kenya

\begin{abstract}
The innovative and sustainable economic development of a country depends not only on the presence of a strong government, universities and industries but more so on how they mutually interact for strategic objectives. The evolution of these interactions has given rise to science parks, technopolis, and at more advanced stages to innopolis. Further, common economic- and market-driven innovative demands and goals of the trio have caused the emergence of clustering and concentration of experts in various fields. However, the development and growth of the service sector, Internet and globalization have created the need for informed watchdogs for the sustainable interactions in the triple helix. Studies have revealed that the evolution of the interactions of the innovation models has increasingly raised the necessity of a strong civil society in the triple helix. This development has now transformed the triple helix into the quad helix as it is discussed in this paper. There is an urgent need for developing and middle-income countries to learn and implement the discussed global best practices of science park creation in the triple helix settings. This shall revitalize their technological innovation and gradually advance by building the infrastructure needed for competitive economic growth.
\end{abstract}

Keywords: Triple helix, Government, University, Industry, Globalization, Science park

\section{Introduction}

It has been proven through many studies that local sustainable economic development is promoted through various initiatives that link universities, government and industries (UGI) (Etzkowitz and Leydesdorff, 1995; 2000) leading to the creation of science parks (Afonso et al., 2010). Countries which have not advanced in linking the three (UGI) have yet to realize that although scientific research can be powerful, it is not the only organized human activity that produces sustainable innovation ecosystems relevant to the development of viable economic policies that meets societal needs (Gibbons et al., 1994; Carayannis and Campbell 2006). It is an almost common consensus that development arises as a result of cooperating and strategically consulting specialized productive units that are complementary. Since the 2000s, a series of new ways regarding models for sustaining innovation systems has taken place in order to accommodate global networking. This has been enhanced by the need for food

(c) 2016 Kimatu. Open Access This article is distributed under the terms of the Creative Commons Attribution 4.0 International License (http://creativecommons.org/licenses/by/4.0/), which permits unrestricted use, distribution, and reproduction in any medium, provided you give appropriate credit to the original author(s) and the source, provide a link to the Creative Commons license, and indicate if changes were made. 
safety, green energy and other international agreements caused by technological advances and the speeding up of access to resources (Powell and Grodal, 2005).

The triple helix innovation model based on strategic interactions of UGI has played both integrated and overlapping roles for the benefit and sustainability of economic development in many countries. Analysis showed that economies where the triple helix has been operational had knowledge-based development and have created industries that are innovation-driven. Moreover, the universities in these countries have spurred technology-intensive research (Etzkowitz and Klofsten, 2005). There have been several advances in the triple helix model due to the need to maximize the benefits realized by the mutual interaction of the integrated innovation ecosystem.

There has been a problem in advancing and sustaining technological development in developing countries especially in Africa. This has made them lag behind in stimulating innovations needed to either compete in global markets or to make their higher education relevant to market demands. This paper examines critically some of the perceived knowledge gaps which most developing countries have not cracked in understanding the drivers of the technological edge. The paper goes back in the primordial stages and systematically outlines the evolution of these changes and discusses the crucial role of each stage of interaction. We suggest that the growth of each stage in the triple helix as it advances to quad helix is very important for establishing a sustainable developmental ecosystem. Furthermore, each stage should advisedly be implemented. There are factors that have contributed to these interaction changes, for example, Leydesdorff and Sun (2009) reported that in Japan the government, university and industry relations had actually started to decline, because of differences in strategic intentions. This was much more conspicuous in the university-industry collaborations. However, there have been explicit policies to stimulate these relations and some have succeeded. Furthermore, analysis of the quadruple helix concept showed that it is not yet a very well-established concept in innovation research and policy in some countries (Arnkil et al., 2010), but its adoption and implementation seem that it is becoming increasingly paramount in a globalized society. The objective of this work is to highlight and explain the past developments of the GUI interactions and how they are imperative in sustainable development of a country.

\section{Review}

The interactions of the triple helix innovative model in Third World Countries

The governments, universities and industries in the third world countries, especially in Africa, have not been creating new business opportunities and have passively been watching as former famous industries head to oblivion. They are also not fostering entrepreneurship, and hence, hardly are they having a mechanism of generating knowledge-based jobs. Much money has been spent in trying to discover what could be the cause of this situation. But, it is now becoming increasingly clear that this has been caused by lack or little interaction between the government, universities and industries. They in fact practically work in independent silos as shown in Fig. 1.

\section{How the triple helix works is operating in the middle-income nations}

In the middle-income countries, the governments are making demands for universities to participate and contribute to long-term strategic plans for the countries. This 


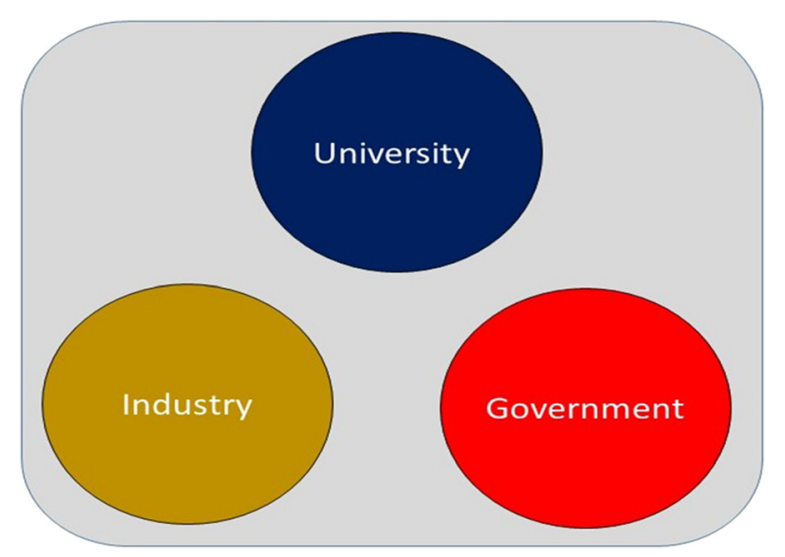

Fig. 1 The operation of the government, university and industry interaction in the Third World is almost with no meaningful interactions. It seems to be a kind of silo confinement for each institution

has made governments and universities sign annual performance contracts, and reciprocally, the universities have demanded the government to provide the necessary technological infrastructure. It seems that at this stage the governments are at crossroads to either be competitive in international markets or lose the support of former donors. Hence, the governments in a bid to keep afloat are pushing the industries to brand their economies with innovative products and create employment for the growing populations. This has made them start negotiations with local industries and at the same time attract investments in order to create jobs and competitive products. On the other hand, the industries have also demanded for a better innovative environment with friendly taxes and better marketing infrastructure. This kind of economic push and technological pull has made interactions between government, universities and industries begin to be established (see Fig. 2). It is not an easy process to initiate, but logic has shown that it is the only way for a sustainable competitive economic growth which is mutually beneficial.

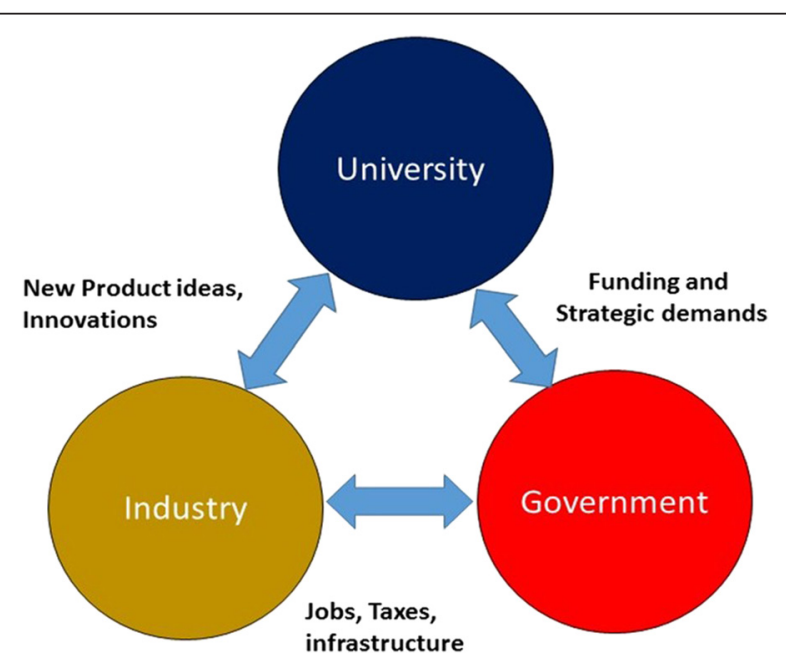

Fig. 2 The beginning of strategic interactions between governments, universities and industries in middle-income countries. This is usually triggered by the push for economic growth and the pull for a competitive market-driven technological advancement 
The triple helix in the developed nations

The operation of the triple helix in the developed countries has actually matured in bringing the governments, universities and industries closer over the years. This has made them identify cross-cutting issues which none of them can adequately deal with individually. These common issues include energy, information technology and communication (ICT) and transport. The commonality of the challenge has brought them together so as to find sustainable innovative ways of tackling them. In many cases, they ended up identifying a physical place close to the universities to meet regularly for innovative discussions. This venue for representative experts was in many places globally called a science park. The concept has matured over decades in many countries and has been the source of great innovations. For example, the Bluetooth technology innovation, and its marketing which is common in computers and mobile phones, was developed by the Lund University, Sweden, based on this interactive background. This is basically the technological secret of developed countries. The innovations in these countries have greatly increased because of these interactions and have made big technological cities called technopolis and later innopolis.

The governments in these countries fund strategic research in universities as demanded by the need for new products in industries and the need to create jobs. The outcome usually makes them more globally competitive. Although the science park is mainly the main outcome or focus of such interactions, we also have other dual peripheral interactions in the triple helix components (see Fig. 3).

\section{The evolution of triple helix at the globalization scale}

The triple helix has benefited industries by enabling them to obtain informed labour from universities by linking market demands to experts in the field and obtaining sustainable licensing agreements. The governments have been able to initiate new industries and new products leading to more jobs for citizens. They also have gotten more taxes and duties leading to a higher status of living and economic development. The universities have benefited from the science parks by getting reliable sources of funding from industry and government and better training in industry-related research good for

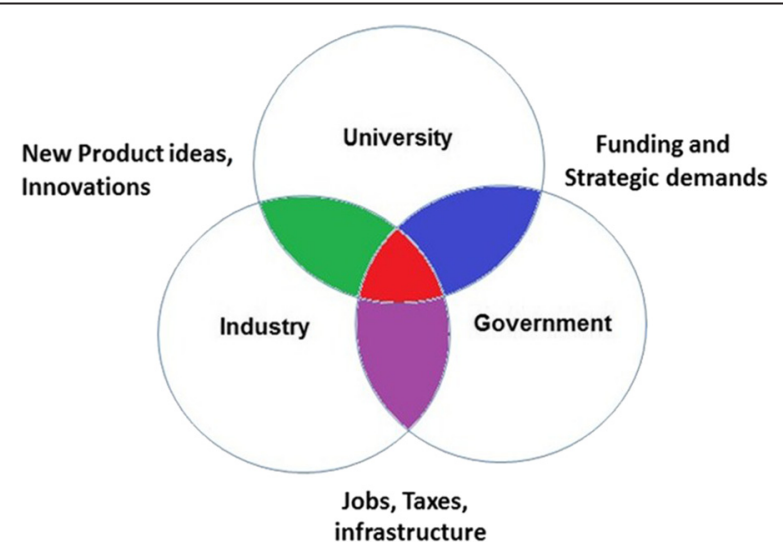

Fig. 3 The closer interaction between government, universities and industries in developed countries based on cross-cutting issues from the science park (indicated as red). This kind of interaction is the basis and sustainable strategy for technological innovation necessary for creating local jobs and maintaining international product competitiveness in markets 
quicker job placements. They also have been able to do research which is based on national and global needs.

The inclusion of the Internet has made the world become so small especially after the increase and the impact of the service sector in economic development. This has led to globalization. There are clear benefits of globalization like the provision of a platform for advocacy of human rights and safety which have to be addressed in the economic interactions of the triple helix. But, the citizens or users cannot directly always voice their informed concerns to the government, universities or industries, but a strengthened civil society has been suggested to be much better placed to play the watchdog in the now well-established link between government, universities and industries.

The number of industries and subsectors in a science park always increase, and they end up in the formation of clusters for effective and efficient innovation of products. Therefore, there is need for a specialized body of personnel or think tank to evaluate the sustainability of some of the advances in technology based on economic, social and environmental impacts in various settings. This inclusion of the civil society has made us to suggest the inclusion of the civil society as a fourth component in the triple helix, making a quad helix (see Fig. 4).

\section{The development of technological incubators}

Normally, universities have a local system of producing their own commercial products. Their system is linear, and it includes the doing of research, publishing of findings, patenting of innovations, making of prototypes and then finally making products for industries. This process is normally abbreviated as RPPP, to represent the following: Research, Publish, Patents, Prototype and Product. These products are then expected to be incubated. The role of incubators is to provide an environment for the crossfertilization of technology, marketing and innovation. The incubators provide insights into modalities of management, scalability and marketability logistics for the product in

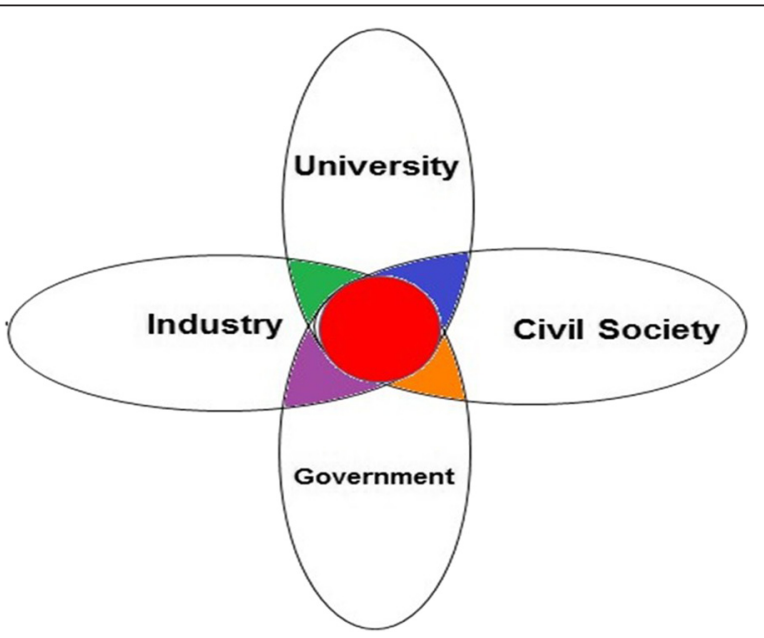

Fig. 4 The advancement of the triple helix to include the civil society as the fourth component makes a quad helix. This inclusion aids in raising the voice of the user of the innovations so as to cater for mainly the social and environmental needs on a global scale. This is because, although for the sake of the global market and product competitions, we are bound to think globally but should always act locally 
the society. A researcher who has undergone incubation process with his or her product is capable of creating jobs and marketing new technologies and is able to build national and international economies. However, although this is absolutely possible, it is not sustainable and it cannot create jobs and products which are globally competitive. Hence, there is need for universities in developing countries and middle-income countries to make a paradigm shift and begin to invest in science park-based innovation models as it is taking place in developed countries.

\section{Discussions and conclusions}

In a knowledge-based system, it is possible to transform products analytically and innovatively so as to make them seem as new products. For example, although the Netherlands does not produce tomatoes, it has become a major exporter of tomatoes due to its strategic innovativeness. Most of the developing countries and those which are even referred to as poor nations also have great entrepreneurs; by this, we mean people who can think and come up with ideas to solve community problems. Therefore, we should encourage them to be ready to launch their ideas and be absolutely responsible for the inherent risks and outcomes. The provision of the necessary infrastructure can provide proactive guidance to deal with the risks involved therein. Someone may ask, so if developing countries have had entrepreneurs, why has economic development been very slow? What has been the problem? We suggest that the problem has been how to put the operational institutions in strategic venues for a sustainable innovation ecosystem. The above analysis makes an outline how the innovative models have evolved since their inception in the 1930s, when the idea of "science park" was coined in the USA.

\section{The introduction of the civil society in the triple helix}

Later studies suggested the insufficiency of the triple helix in long-term sustainable innovative growth and then suggested an addition of a fourth helix, called the civil society (Lijemark, 2004; Khan and Al-Ansari, 2005). Studies suggested that the fourth helix could include faith-based organizations (FBO), non-governmental organizations (NGO), etc. which could combine funding from governmental with the community and private donors (Delman and Madsen, 2007). The civil society serves as the voice of the citizen and could make development to be more human-sensitive and in the cultural context of the communities. Some researchers had chosen the user as the fourth helix of the quad helix. But they confessed that the "user-driven" is problematic as it suggests a bigger role to the user than what there actually often exists. Another recent suggestion was to include a model called "the citizen-centered". It focused on the development of innovations that are relevant and safe for citizens (Arnkil et al., 2010). However, the citizens are hardly able to know the procedures for getting the government and citizen to legally listen to their voices; hence, a strong civil society becomes a very important component for the triple helix. The interactions between the four helices could be varied (Etzkowitz and Leydesdor, 2000). Studies show that the four helices form what is referred to as ecosystems of innovation (Afonso et al., 2010). This shows innovative ideas passing from one source and perfected on a different platform can be supported by another source. New processes or products could start from national innovation demands or by creative citizens. 


\section{The Internet and globalized economies}

The international outlook of products and processes shall give an edge in global economic competition. Globalization shall make the international-national dimension of operation become increasingly relevant (Wagner, 2008). The Internet has caused the service sector to play a major role in economic development in many countries. We are not suggesting that the quad helix is the ultimate, but we are open to new ideas which can make the interaction among government, universities and industries become profitability closer. We have complex issues to deal with in the different sectors in the science parks. Hence, the creation and simulation of better synergies among economy, society, environment, and democracy in the digital era might take its use to other levels.

Competing interests

The author declares that he has no competing interests.

Received: 11 December 2015 Accepted: 22 March 2016

Published online: 01 April 2016

\section{References}

Afonso Oscar, Monteiro Sara, Thompson Maria (2010). A growth model for the quadruple helix innovation theory. FEP working papers. n. 370, April 2010.

Arnkil, R., Järvensivu, A., Koski, P., \& Piirainen, T. (2010). Exploring quadruple helix outlining user-oriented innovation models. Tampere: Tampereen Yliopistopaino Oy Juvenes Print.

Carayannis, E. G., \& Campbell, D. F. (2006). Introduction and Chapiters summaries. In G. C. Elias \& D. F. J. Campbell (Eds.) Knowledge creation, diffusion and use in innovation networks and knowledge clusters. A comparative system approach across the United States, Europe and Asia. Westport, Connecticut: Praeger.

Delman, J. and Madsen, S.T. (2007). Nordic triple helix collaboration in knowledge, innovation, and business in China and India: A preliminary study. NIAS-Nordic Institute of Asian Studies.

Etzkowitz, H., \& Klofsten, M. (2005). The innovating region: toward a theory of knowledge-based regional development. Research and Development Management, 35(3), 243-255.

Etzkowitz, H., \& Leydesdorff, L. (1995). The triple helix-university-industry-government relations: a laboratory for knowledge-based economic development. EASST Review, 14, 14-19.

Etzkowitz, H., \& Leydesdorff, L. (2000). The dynamics of innovation: from national systems and "Mode 2" to a triple helix of university-industry-government relations. Research Policy, 29(22), 109-123.

Gibbons, M., Limoges, C., Nowothy, H., Schwartzman, S., Scott, P., \& Trow, M. (1994). The new production of knowledge, the dynamics of science and research in contemporary societies. London: Sage.

Khan, M.R. and Al-Ansari, M. (2005). Sustainable innovation as a corporate strategy. Intellectual Assets Management, Saudi Arabia. Resource document: http://www.trizjournal.com/archives/2005/01/02.pdf.

Leydesdorff, L., \& Sun, Y. (2009). National and international dimensions of the triple helix in Japan: university-industrygovernment versus international co-authorship relations. Journal of the American Society for Information Science and Technology, 60(4), 778-788.

Liljemark, T. (2004). Innovation policy in Canada. Strategy and Realities. Swedish Institute for Growth Policy Studies, Östersund.

Powell, W.W. and Grodal, S. (2005). Networks of innovators. The Oxford Handbook of Innovation. Oxford University Press, Editors: Fagerberg, J, Mowery, D and Nelson, RR. Rivera-Batiz, L and Romer, P (1991). Economic Integration and Endogenous Growth. Quarterly Journal of Economics.

Wagner, C. S. (2008). The new invisible college. Washington, DC: Brookings Press.

Submit your manuscript to a SpringerOpen ${ }^{\odot}$ journal and benefit from:

- Convenient online submission

- Rigorous peer review

- Immediate publication on acceptance

- Open access: articles freely available online

- High visibility within the field

- Retaining the copyright to your article

Submit your next manuscript at $>$ springeropen.com 